\title{
STUDENTS' PERCEPTION AND MOTIVATION TOWARD ENGLISH E-LEARNING DURING COVID-19 PANDEMIC AT NINTH GRADE OF MTSN 1 SERANG CITY
}

\author{
Fenty Nurhayati Nufus, Anita, Tatu Siti Rohbiah \\ Universitas Islam Negeri Sultan Maulana Hasanudin Banten \\ Serang, Banten \\ fenty.nurhayati19@gmail.com anita.ftk@uinbanten.ac.id Tatu.siti.rohbiah@uinbanten.ac.id
}

\begin{abstract}
COVID-19 pandemic has resulted in the shifting of teaching-learning process replacing with E-learning. This study focus to knowing the students' perception and motivation towards English E-Learning duringgCovid-19 pandemic at MTSN 1 Serang City. This study commonly resolved 2 questions as follows: 1) What are students' perception toward English E-learning during covid-19 pandemic? 2) How are students' motivation toward English E-learning during covid-19 pandemic?. In this research the technique of collecting data researcher used interview and questionnaire method. There were 20 students of ninth graders at MTSN 1 Serang City participated in this research. The instrument of this research is author herself. Because this research investigate the students' perception and motivation from the students' experiences duringgcovid-19 pandemic, this study was applied descriptive qualitative design. The detections from data analysis, students show positive perception toward English E-learning, because with e-learning, the process of learning English has become much easier and E-learning can foster students' interest and motivated in learning English. Even though students found problems in implementing English E-learning, students also found learning English through ELearning is quite effective.
\end{abstract}

Keyword: E-Learning, Perception, Motivation

\section{INTRODUCTION}

Learning is the process of student interaction with educators and learning resources in a learning condition that involves students and teacher who exchange knowledge. Smith (1962:260), learning is the accession of new behavior or strengthening or decreasing of behavior as the outcome of experience. According to Fasold \& Connor (2006:434), learning a foreign language establishes a situation that the community learns and acquires a foreign language, in which a language that is not spoken by the surrounding community.

There are as yet many instructing and learning exercises that focus on eye to eye gatherings in class. Nonetheless, with the coronavirus pandemic far reaching in Indonesia, movements of every kind should be done from home. According to _Directorate General of Disease Prevention and Control, Coronavirus Disease (COVID19) is a new virus that has- yet to be recognized in persons. Covid is a zoonosis (can be sent between creatures or people). 
Mild respiratory tract infections to acute pneumonia, which can cause death by this virus.

The detection of the COVID-19 pandemic, the whole activity including education are disturbed. President of the Republic Indonesia on March 11, 2020, adopted a policy for the moment closing the teaching and learning activities and urges them to study at home, and break the virus chain with E-learning. This has resulted in the emergence of a new learning system in which each student is required to keep learning, regardless of the time or place.

At the school level, such as at MTSN 1 Serang City, the E-learning process is the most solution adopt. This is done with E-learning, which can be acquired by teachers and students whenever and wherever they choose as long as there is an internet connection. E-learning can be used to speed up the learning process.

According to Indrakusuma and Putri (2016:2), E-learning is the new ways in the teaching and learning process with compendium of electronic learning which is uses the internet as a learning system with electronic media. Ghiardini (2011:9) affirmed E-learning can provide an effective learning technique, such as training with a partner, personalizing the learning experience according to the needs of the learner, compound cooperative project with individualistic study, and it can be carried out anytime and everywhere.

Indrakusuma and Putri (2016:5) has stated four characteristics of E-Learning: (1) Students' attractiveness to learning materials prohibition gamble on the teacher/leaner, since students can build their teaching materials provided by the website interface, (2) Source knowledge is all over the place and can be effortlessly gotten to everybody. The fact that the internet is a worldwide medium that can be acquired with everybody attached to it, (3) Educational institutions or learners acts as a mentors or mediators, (4) Procured through the reorganization of training framework arrangements, educational program, and the executives can support the use of data and correspondence innovation for training ideally.

According to Kassimova, Issaliyeva and Kosherbayeva (2019), there are three benefits of E-learning: (1) Each student can ask questions online and receive feedback from the teacher, and they can also talk over problems in online classrooms with a combination of theory and practice, (2) Students are not connected in a virtual environment because they communicate in learning, (3) E-learning drives understudies to learn and foster themselves autonomously. It urges to work on their 
insight and critical thinking abilities while finishing task.

According to Robbins and Timothy (2008:166), Perception is the internal process that organizes and interprets an individual's sensory impressions to give meaning to the individual's environment. There are differences between individuals by liking an object and disliking an object, its' a hot topic right now because of how individuals handle objects with their perceptions. Students' perceptions can be known as students' competence to justify their own opinions and distinguish them from the research class. Student perception is the steps students clarify and understand what they feel, as explained above.

Qiong (2017:18), -process of perception there are three steps, as follows: (1)_Selection, the environment occasion become important experience,

Organizations, This step is carried out by placing objects or people into categories, which are known as categorization by some researchers, (3)_Interpretation, prompts the interaction of connecting significance to the chose upgrades, when the chose improvements have been sorted into construction and stable examples, we attempt to seem ok if these designs by allocating implications to them.

While Robbins \& Judge (2008:203) stated Motivation is a proceeding in express a humans' persistence, management, and intensity in an attempt to attain goals. Saptono (2016:190) has stated that Motivation will influence students to be active in learning and help obtain high learning outcomes. Motivation is one of the roles that facilitate students to learning. Teachers determine what is important to learn and use many things to increase student motivation.

Gardner and Lambert (1972) has divided motivation into two variables, (1) Instrumental motivation occurs when an external factor motivates a person to perform a task and is derived from an external source that encourages individuals to achieve success, (2) Integrative motivation is derived from within, It is critical for individuals to demonstrate student success in learning languages.

Halim Purnomo (2019:89) has stated there are two types of motivation, as follows: (1) Intrinsic motivation is a change that occurs in a person, a state of feeling dissatisfied or psychological tension, (2) Extrinsic motives are motives that are active and functional because there are external stimuli.

However, e-learning is still referred to as a breakthrough or up to date style in teaching and learning activities which teachers and students do not need to be present in the classroom in the process of 
teaching and learning activities. They only use the internet to carry out learning activities, which can be remote. The effectiveness of this English E-learning method can be seen in the attitudes and motivations of the students.

From the explanation above, Researcher is encouraged to explore students' perceptions and motivations after learning through E-Learning during_covid19 pandemic, because the_Covid-19 pandemic has suddenly arrived the learning process carried out through E-learning. However, because not every employee is understood with the E-Learning method, this is a up to date situation that oblige adjustment.

\section{METHOD}

This research was conducted in descriptive qualitative research. Descriptive research narrate and explains past incidents, circumstances, or situations. The goal of a descriptive is to provide as much information as possible on what is going on right now, such as how students learn, how gurus teach, and what kind of classroom is available at any given time in any given location.

This research will conducts online because all learning activities in the Covid19 outbreak were carried out from home. The respondents of this research are student of ninth grade at MTSN 1 Serang City, the most important thing, the students are participate in English online learning innCovid-19 pandemic. The researcher choose ten students of 9A class and ten students of 9B class as informants, to fill out the interviews and questionnaires.

The questionnaire method by using closed questions for respondents to answer. The questionnaire consists of five closed questions that focused on students' perceptions and five closed questionssthat attentive on students' motivation of English E-Learning during theeCovid-19 pandemic. The interview consists of 10 questions that focused on students' perception and motivation toward English E-Learning during Covid-19 pandemic, with additional questions to support the data obtained. The Researchers formed an electronic questionnaire with Google Form, and spread out to Whatsapp groups ninth grade of students at MTSN 1 Serang City.

In this research uses triangulation techniques to validate the data. Investigating reality of specific data through different techniques and wellsprings of information procurement. The analyst is contrasting information gathered from polls and meetings to get better results. 


\section{DISCUSSION}

The result of the research were obtained from 20 participants consist of 10 students of $9 \mathrm{~A}$ class and 10 students of $9 \mathrm{~B}$ class, the most important thing, the students are participate in English E-learning innCovid-19 pandemic. Based on questionnaire in the findings from students' perception and motivation as follows:

\section{1) Students' perception}

The first statement, with e-learning, the process of learning English has become much easier. The result indicate students (Strongly Agree 25\%, Agree 40\%, Disagree $35 \%)$. It can be interpreted that most of the students feels the activity of learningeEnglish through E-learning is easier.

The second statement is the Englishmaterial distributed by the tteacher with ELearning easy to understand for students. The result indicate students (Strongly Agree $30 \%$, Agree 50\%, Disagree 20\%).It can be conclude most of the students agree the English material distributed by -the teacherr with E-Learning easy to understand.

The third statement is the -teacher has question and- answer activities regarding English materiall with e-learning. The result indicate students (Strongly Agree $10 \%$, Agree $45 \%$, Disagree $45 \%$. It can be interpreted that most of the students agree and disagree with the statement
The fourth statement is students' English skills better while learning by ELearning. The result indicate students (Strongly Agree 20\%, Agree 70\%, Disagree $10 \%$. It can be conclude that most of the students' English skills better while learning by E-Learning.

The fifth statement is the learning English with E-Learning makes the learning process effective. The result indicate students (Strongly Agree 30\%, Agree 35\%, Disagree $35 \%$. It can be conclude that most off the students- agree and disagree with the effective learning English through Elearning.

\section{2) Students' Motivation}

The first statement, students asks the teacher if they struggling in learning Englishh by E-Learning. The result indicate students (Strongly Agree 35\%, Agree 35\%, Disagree $30 \%$. It can be conclude, most off the students strongly agree and agree that students ask thee teacher when they have struggling in learning English by ELearning.

The second statement is students remain learning English although they be without assignments during E-Learning. The result indicate students (Strongly Agree $20 \%$, Agree $75 \%$, Disagree 5\%. It can be conclude, most of the students agree and strongly agree and students remain learning 
English although they be without assignments during E-Learning.

The third statements is students never delay doing English assignments during E-learning. The result indicate students (Strongly Agree 30\%, Agree 55\%, Disagree 15\%). It can be conclude most of the students agree and strongly agree that students never delay doing English assignments during E-learning.

The fourth statement is students feel lost out if they don't take English learning through E-Learning. The result indicate students (Strongly Agree 65\%, Agree 30\%, Disagree $5 \%$. It can be conclude most of the students strongly agree and agree that students feel lost out if they don't take English learning through E-Learning.

The fifth statement is students feel motivated and interest on learning English with E-Learning duringgCovid-19 pandemic. The result indicate students (Strongly Agree 15\%, Agree 60\%, Disagree $25 \%$. It can be conclude that most of the students agree with that students feel lost out if they don't take English learning through E-Learning.

Based on interview in the findings from students' perception and motivation as follows:

\section{1) Students' Perception}

The first question is "Do you think with e-learning, the process of learning
English has become much easier?". The result indicate most off students answer that learning English with E-learning is easy to operate for the student learning activity, because the features that are uncomplicated to understand and being able to facilitate communication between students and teacher.

The second question is "Do you think the English material that distributed by- the teacher through E-Learning easy to understand?". The result indicate most of students answer the English material distributed by the teacher thhrough Elearning is easy to understand, because the material previously explained can be repeated anytime and anywhere and also students can search for other references on Google.

The third question is "Is it possible for a teacher to conduct a question -and answer activity about -English language material during an E-Learning course?". The result indicate the teacher execute question -and answer activities in the end of the material. Although the teacher do not hold question and answer activities very often, but if the learning process uses zoom or Google meet, the teacher will definitely do it.

The fourth question is "Is it true that your English skills will improve when you learn through E-Learning?”. The result 
showed most of the students answer their English skills better when learning by Elearning, because learning English through E-learning can be done by self-study, which students can gain insight into English material by searching the internet or watching English videos.

The fifth question is "Is it possible to study English effectively via E-Learning duringgCovid-19 pandemic?". The result showed learning English by E-learning is quite effective, because with E-learning can adds insight into English lesson. In addition, students have more time to accept the learning material and repeat the material that has been explained. Although with Elearning sometimes there are problems such as limited internet quotas and signal, and the atmosphere of offline and learning online is much different.

\section{2) Students' Motivation}

The first question is "Do you have any questions for your teacher if you're having trouble learning English through ELearning?". The result indicate that some students want to ask questions to the teacher and some don't. Students ask when the difficulty of the homeroom teacher recommends asking questions to the teacher concerned via Whatsapp personal chat. Although, few students who depend on Google to get response for their questions and discuss material that is not understood with friends or asks people at home, such as brother/sister, father and mother. It can be concluded that, there are few students who areaquite indifferent because of various factors such as fear of asking questions.

The second question is "Do you remain learning English although you be without tasks during theeCovid-19 pandemic?". The result of this question indicate that most of students still learn English although they don't have assignment, usually they learn by practicing answering questions, reading the material in the LKS, memorizing some difficult words, or repeating previously explained material. There are some of students still learn because before from elementary school they already like English. It can be achieve that students' motivation is very good in learning English, although they be without task during the pandemic.

The third question is "if there is an assignment given by the teacher, is it done immediately or postponed?". The result showed that most of students answer they immediately do the assignment given by the teacher. Majority of students doing their work immediately because they think that delaying doing the task will increase the burden because there will be more tasks coming in because they think that delaying doing the task will increase the burden because there will be more, they also afraid 
to forget the assignment. Some students also did not do assignments immediately, because depending on the situation, if there are many task and they will do the task with the fastes deadline. It can be conclude that students' motivation in doing their assignments diligently is very good.

The fourth question is "Do you feel lost out if you don't take English learning through E-Learning?". The result off this question showed that most of students feel lost out if they don't take English learning through E-Learning. They feel a loss because if they don't take English lessons, they will be left behind in the subject matter and of course there will be a lot of material that is not well understood. Moreover, they are already in the ninth grade, which in the future will be difficult if the material is left behind. It can be conclude, Students' motivation in participating doing -learning English through E-learning is very good.

The fifth question is "Is it possible for you to be enthusiastic and motivated regarding learning English via E-Learning duringgCovid-19 pandemic?'. The result of this interview showed that most of the students -were motivated and -enthusiastic, students thought learning English via Elearning more fun.

Findings/Results section may infer the facts or data that you encountered or you collected during research. It will be better to have tables and figures that represent your result. Give a concise description on the tables or figures regarding your findings. Furthermore discussion section reflects whether your methodology works on the issue you address. This section should provide the answer of the problem. This section is not repeating what you have mentioned in Findings/Results section.

\section{CONCLUSION}

Students' perception toward English E-learning duringgcovid-19 pandemic is quite good, because the process of -learning English is eeasier with E-learning and also a good alternative way to do learning in the era covid-19 pandemic. They also contend this -method is quite effective for learning English, because the English-material distributed by the-teacher with E-Learning easy to understand, in addition their English skills better. Although students give positive perception, they found problems in implementing English E-learning, such as internet signal, quotas and rarely of question and answer interactions during online learning.

Most of students stated learning English with E-learning is quite good motivating and interesting. It can be seen from most of students assk the -teacher when they struggling in learning-English 
with E-Learning, and some of students asks to the friends, search on Google and Youtube, students remain learning English although they be without assignments during E-Learning, students feel lost out if they don't take English learning through ELearning and they understand the influence off learning English while at home. Although most of students stated learning English via E-learning is motivating, many of them believe learning in a class setting is more enjoyable because they can interrelate with their teachers and classmates in a more relaxed setting.

\section{REFERENCES}

Bimo, Walgito. Pengantar Psikologi Umum. Yogyakarta: C.V. Andi, 2010.

Chen, Yining., and Leon B Hoshower. "Student Evaluation of Teaching Effectiveness: An Assessment of Student Perception and Motivation". Dalam Carfax Publishing, Vol. XXVIII, No. 1,_(2018): 71-88.

David and Lamb, Clarice. The Self Directed Learning. Managing the Learning Process. New York: Cambridge University Press,_1996.
Delahunty, G. P., and Garvey, J. J,. The English Language: From Sound to Sense. Fort Collins, Colorado: WAC Clearinghouse,_2010.

Direktorat Jenderal Pencegahan dan Pengendalian Penyakit (P2P). Pedoman Pencegahan dan Pengendalian Coronavirus Disease (Covid-19). Jakarta Selatan: Kementerian Kesehatan RI, 2020._ Fasold, R. W., \& Connor-Linton, J. An Introduction to Language and Linguistics. New York: Cambridge University Press, 2006.

G. K. Kassymova, S. T. Issaliyeva and A. N. Kosherbayeva, "E-Learning and Its Benefit for sStudents", Pedagogics and Psychology Journal, Vol. 18, No. 4, (December, 2019): 249-255.

Gardner, R. C., \& Lambert, E. Attitudes and Motivation in Second Language Learning. Rowley, Mass: Newbury,_1972.

Geoffrey Broughton, Teaching English as a Foreign Language, New york: Routledge, 2003.

Ghiardini, B._E-Learning Methodologies: A Guide for Designing and Developing E-Learning Courses. Rome: FAO,_2011.

Indrakusuma, A. H., and Putri, A. R. ELearning: Teori and Design. 
Tulungagung: $\quad$ STKIP PGRI

Tulungagung,_2016.

Naidu, S. E-Learning: A Guidebook of Principles, Procedures, and Practices Revised Edition. New Delhi: Commonwealth Educational Media Center of Asia, 2006.

Purnomo, Halim. Psikologi Pendidikan, Yogyakarta: LP3M UMY, 2019.

Qiong, OU. “A Brief Introduction to Perception". Dalam Studies in Literature and Language, Vol. 15, No. 4 (2017): 18-28.

Robbins, Stephen P and Timothy A. Judge, Organizational Behaviour Fifteenth _Edition, (Boston, Pearson Education, 2008.

Saptono, Y. J. "Motivasi dan Keberhasilan Belajar Siswa". Dalam Jurnal Pendidikan Agama Kristen Regula Fidei, Vol. I, No. 1 (2016):_189212.

Schunk, D. H. Learning Theories: An Educational Perspective Sixth Edition. Boston, MA: Pearson Education, 2012.

Smith. Psychology in Teaching. USA: Prentice Hill, 1962. 